\title{
Penapisan dan Promosi Kesehatan Diabetes Melitus pada Karang Werda Sejahtera Surabaya
}

\author{
Abdur Rivai ${ }^{1}$, Nugrahadi Dwi Pasca Budiono², Alifananda Nur Mahmudah ${ }^{3}$. \\ ${ }^{1,3}$ Program Studi D3 Farmasi, Fakultas Kesehatan, Universitas Muhammadiyah Gresik \\ ${ }^{2}$ Program Studi S1 Kesehatan Masyarakat, Fakultas Kesehatan, Universitas Muhammadiyah Gresik \\ E-mail correspondennce: h.abdurrivai@umg.ac.id.
}

\begin{abstract}
Abstrak
Karang werda didirikan dengan tujuan untuk mendorong dan meningkatkan aktivitas para lanjut usia sehingga semakin mampu untuk mengembangkan diri dalam melaksanakan fungsi sosial ekonomi di masyarakat lingkungannya. Prevalensi Diabetes Melitus berdasarkan Diagnose Dokter pada tahun 2018 untuk usia lanjut sebesar $15,6 \%$, berdasarkan jenis kelamin pada perempuan 1,8\% dan Pria 1,2\%, berdasarkan tempat tinggal $1,9 \%$ di perkotaan dan $1 \%$ di pedesaan. Tujuan pengabdian kepada masyarakat adalah untuk mengetahui status kadar gula darah melalui kegiatan penapisan Diabeter Melitus dan memberikan pengetahuan tentang penyakit Diabetes Melitus. Metode yang digunakan dalam pengabdian masyarakat adalah pemeriksaan kadar gula sewaktu dengan menggunakan Multi Monitoring System Autocheck, melalui pembuluh darah perifer, yang diambil pada ujung jari tangan dan promosi kesehatan tentang penyakit Diabetes Melitus. Hasil kegiatan ditemukan suspek Diabetes Melitus sebesar 5,56\%, sedangkan dengan status normal sebesar 81,48\%, 4\% yang berjenis kelamin laki-laki suspek Diabetes Melitus, 7\% dari yang berjenis kelamin perempuan suspek diabetes melitus, $11 \%$ dari yang status gizi kegemukan suspek Diabetes Melitus, promosi kesehatan tentang upaya pencegahan penyakit diabetes melitus telah dilaksanakan, diikuti oleh 54 orang dan mendapatkan perhatian dengan antusias.
\end{abstract}

Kata Kunci : Diabetes Melitus, Usia Lanjut, Penapisan, Promosi Kesehatan

Abstract
Karang werda was established with the aim of encouraging and increasing the activities of the elderly so that they are increasingly able to develop themselves in carrying out socioeconomic functions in their surrounding communities. The prevalence of Diabetes Mellitus based on Doctor's Diagnosis in 2018 for the elderly is 15.6\%, based on gender in women $1.8 \%$ and men $1.2 \%$, based on residence in $1.9 \%$ in urban areas and $1 \%$ in rural areas. The purpose of community service is to find out the status of blood sugar levels through screening for diabetes mellitus and to provide knowledge about diabetes mellitus. The method used in community service is the examination of sugar levels while using the Autocheck Multi Monitoring System, through peripheral blood vessels, taken at the tip of the fingers and health promotion about Diabetes Mellitus. The results of the activity were found to be Diabetes Mellitus suspects of $5.56 \%$, whereas with normal status of $81.48 \%$, 4\% were male suspects of Diabetes Mellitus, 7\% of those who were suspected of having Diabetes Mellitus, 11\% of those with status obesity nutrition suspected of diabetes mellitus, health promotion about efforts to prevent diabetes mellitus has been carried out, attended by 54 people and received attention with enthusiasm.

Keywords: Diabetes Mellitus, Elderly, Screening, Health Promotion

\section{PENDAHULUAN}

Pembangunan kesehatan yang kita laksanakan bertujuan untuk meningkatkan kesadaran, kemauan dan kemampuan hidup sehat bagi setiap orang agar terwujud derajat kesehatan masyarakat yang setinggitingginya, sebagai investasi bagi pembangunan sumber daya masusia agar produktif baik secara ekonomi maupun sosial. Kesehatan adalah hak setiap orang, untuk mendapatkan pelayanan kesehatan yang 
aman, bermutu, dan terjangkau, sesuai dengan kebutuhannya masing-masing, tetapi dilain pihak kesehatan merupakan kewajiban setiap orang, untuk ikut mewujudkan, mempertahankan, dan meningkatkan derajat kesehatan masyarakat yang setinggi-tingginya. Salah satu kelompok yang harus mendapatkan pelayanan kesehatan adalah kelompok lanjut usia. Lanjut usia atau sering disebut Lansia adalah seseorang yang telah mencapai usia 60 tahun [1].

Untuk menampung kegiatan para usia lanjut guna membantu mewujudkan kesejahteraan, maka dibentuk organisasi Karang Werda. Karang werda didirikan dengan tujuan untuk mendorong dan meningkatkan aktivitas para lanjut usia sehingga semakin mampu untuk mengembangkan diri dalam melaksanakan fungsi sosial ekonomi di masyarakat lingkungannya.

\section{Analisa Situasi}

Salah satu karang werda di Kota Surabaya adalah Karang Werda Sejahtera Kelurahan Bendul Merisi Kecamatan Wonocolo Kota Surabaya. Wilayah Kelurahan Bendul Merisi terdiri dari 12 RW dan 58 RT, Jumlah penduduk Kelurahan Bendul Merisi adalah 17.714 jiwa, yang terdiri dari Pria 8.834 jiwa atau $49,87 \%$ dan wanita 8.880 jiwa atau $50,13 \%$, dengan jumlah Kepala Keluara 12.333 orang. Jumlah penduduk berumur 57 tahun ke atas sebesar 1.842 atau 10,4\%. Agama terbanyak adalah Islam sebesar 14.302 atau $81 \%$, Pendidikan terbesar SD sebesar 15\%, diikuti SMU/SLTA sebesar 11\%. Pekerjaan terbanyak adalah Swasta sebesar 5.027 atau 28\%. Kelurahan Bendul Merisi memiliki sarana Kesehatan yaitu 1 Puskesmas Pembantu dan 1 Pos Kesehatan Kelurahan [2]

Visi Karang Werda Sejahtera Kelurahan Bendul Merisi Kecamatan Wonocolo Surabaya adalah Lanjut Usia Sehat, Mandiri dan Berkualitas[3].

\section{Permasalahan Mitra}

Usia lanjut rentang penyakit, oleh karena semakin umur bertambah fungsi fisiologis seseorang mengalami penurunan akibat proses penuaan disamping itu terjadi proses degenerasi sehingga daya tahan tubuh semakin menurun, sehingga hal ini yang menyebabkan usia lanjut makin bertambah umur makin rentan terhadap penyakit. Terdapat sepuluh
(10) masalah kesehatan pada usia lanjut Diabetes menempati urutan nomor 5 dari masalah kesehatan pada lanjut usia, dengan prevalensi tertinggi pada usia 55 sampai 64 tahun yaitu sebesar 5,5\%. Berdasarkan Survei Kesehatan Nasional Prevalensi Diabeter Melitus berdasarkan prevalensi Diabetes Melitus berdasarkan pemeriksaan darah pada penduduk 15 tahun atau lebih didapatkan $8,5 \%$, yang naik jika dibandingkan pada tahun 2013 sebesar 6,9\% Prevalensi Diabetes Melitus berdasarkan Diagnose Dokter pada tahun 2018 untuk usia lanjut sebesar $15,6 \%$ dengan perincian umur 5564 tahun sebesar 6,3\%, umur 65-74 tahun sebesar 6\%, dan beumur 75 tahun atau lebih sebesar 3,3\%. Berdasarkan jenis kelamin pada perempuan 1,8\% dan Pria 1,2\%.. Berdasarkan tempat tinggal $1,9 \%$ di perkotaan dan $1 \%$ di pedesaan.[4].

Karang Werda Sejahtera Kelurahan Bendul Merisi Kecamatan Wonocolo Kota Surabaya, merupakan salah satu Karang Werda di Kota Surabaya yang memberikan pembinaan pada Lanjut Usia, yang dilakukan setiap bulan, pada hari Rabu minggu ke tiga (3). Karang Werda merupakah wadah siraturahmi bagi para anggota dan sebagai sarana untuk memberikan informasi dari pemerintah Kelurahan kepada masyarakat, selain itu anggota juga mendapatkan informasi segala bidang termasuk agama dan kesehatan.

\section{Tujuan pengabdian kepada masyarakat}

1. Mengetahui status kadar gula darah anggota Karang Werda Sejahtera melalui kegiatan penapisan Diabeter Melitus.

2. Memberikan pengetahuan tentang penyakit Diabetes Melitus yang meliputi pengertian, faktor risiko, pencegahan dan penanganannya.

\section{Materi}

\section{Usia Lanjut}

Kesejahteraan Lanjut Usia atau Lansia, yang dimaksud lanjut usia adalah seseorang yang telah mencapai usia 60 tahun ke atas [6]. Hal ini senaga dengan World Health Organisation atau WHO, Lanjut usia adalah seseorang yang telah berumur 60 
tahun keatas. Lanjut Usia merupakan salah satu kelompok umur pada siklus hidup manusia. Kelompok Lanjut Usia merupakan kelompok yang telah memasuki tahapan akhir dari fase kehidupan manusia [5]

Masalah kesehatan pada usia lanjut berawal dari kemunduran sel-sel tubuh, sehingga fungsi dan daya tahan tubuh menurun, serta faktor resiko terhadap penyakit akan meningkat. Masalah-masalah tersebut antara lain malnutrisi, gangguan keseimbangan, kebingungan mendadak, selain itu beberapa penyakit yang sering terjadi pada lanjut usia antara lain hipertensi, gangguan pendengaran, gangguan penglihatan, osteoporisis dan diabetes melitus.

Berdasarkan Undang-Undang RI Nomor 36 Tahun 2009 tentang Kesehatan, upaya pemeliharaan kesehatan bagi lanjut usia ditujukan untuk menjaga agar tetap hidup sehat dan produktif secara sosial maupun ekonomi. Selain ini Pemerintah wajib memberikan jaminan ketersediaan pelayanan kesehatan dan menfasilitasi kelompok lanjut usia untuk tetap hidup mandiri dan produktif baik secara ekonomi maupun secara sosial [6]

\section{Diabetes Melitus}

Diabetes Melitus adalah gangguan metabolisme yang secara genetis dan klinis termasuk heterogen dengan manifestasi berupa hilangnya toleransi karbohidrat.dengan manifestasi berupa hiperglikemi puasa, hiperglikemi posprandial, aterosklerotik, penyakit vaskuler mikroangiopati dan neuropati,[7]. Menurut WHO, Diabetes Melitus didefinisikan sebagai suatu penyakit atau gangguan metabolisme kronis dengan multi etiologi yang ditandai dengan tingginya kadar gula darah disertai dengan gangguan metabolisme karbohidrat, lipid dan protein sebagai akibat dari insufisiensi fungsi insulin. Diagnosis DM [8] berdasarkan hasil pemeriksaan glukosa plasma darah menurut WHO (1999) dan American Dibetes Association (2003) adalah sebagai berikut:

1) Kurang dari $140 \mathrm{mg} / \mathrm{dL}$ dinyatakan tidak Diabetes Melitus

2) $140 \mathrm{mg} / \mathrm{dl}$ sampai $200 \mathrm{mg} / \mathrm{dL}$ dinyatakan TGT atau Toleransi Glukosa Terganggu.
3) Jika lebih dari $200 \mathrm{mg} / \mathrm{dL}$ dinyatakan Diabetes Melitus.

Klasifikasi DM berdasarkan etiologis DM [9] adalah sebagai berikut"

1) Tipe 1 Destruksi sel beta, umumnya menjurus ke defisiensi insulin absolut

(1) Autoimun

(2) Idiopatik

2) Tipe 2 Bervariasi, mulai yang dominan resistensi insulin disertai defisiensi insulin relatif sampai yang dominan defek sekresi insulin disertai resistensi insulin

3) Tipe lain

(1) Defek genetik fungsi sel beta

(2) Defek genetik kerja insulin

(3) Penyakit eksokrin pankreas

(4) Endokrinopati

(5) Karena obat atau zat kimia

(6) Infeksi

(7) Sebab imunologi yang jarang

(8) Sindrom genetik lain yang berkaitan dengan DM

(9) Diabetes mellitus gestasional

\subsubsection{Pelayanan Kesehatan}

Upaya Kesehatan Kesehatan adalah setiap kegiatan dan/atau serangkaian kegiatan yang dilakukan secara terpadu, terintegrasi dan berkesinambungan untuk memelihara dan meningkatkan derajat kesehatan masyarakat dalam bentuk pencegahan penyakit atau preventik, peningkatan kesehatan atau promotif, pengobatan penyakit atau kuratif dan pemulihan kesehatan atau rehabilitatif yang dilakukan oleh pemerintah dan/atau masyarakat [6]. Pelayanan kesehatan promotif adalah suatu kegiatan dan/atau serangkaian kegiatan pelayanan kesehatan yang lebih mengutamakan kegiatan yang bersifat promosi kesehatan. Pelayanan kesehatan preventif adalah suatu kegiatan pencegahan terhadap suatu masalah kesehatan atau penyakit. Pelayanan kesehatan kuratif adalah suatu kegiatan dan/atau serangkaian kegiatan pengobatan yang ditujukan untuk penyembuhan penyakit, pengurangan penderitaan akibat penyakit, pengendalian penyakit, atau pengendalian kecacatan agar kualitas penderita dapat terjaga seoptimal mungkin. Pelayanan kesehatan rehabilitatif adalah 
kegiatan dan/ atau serangkaian kegiatan untuk mengembalikan bekas penderita ke dalam masyarakat sehingga dapat berfungsi lagi sebagai anggota masyarakat yang berguna untuk dirinya dan masyarakat semaksimal mungkin sesuai dengan kemampuannya. Pemberian keempat (4) pelayanan di atas dikenal dengan pelayanan paripurna.

\section{Penapisan}

Skrining atau penapisan merupakan proses pendeteksian kasus atau kondisi kesehatan pada populasi sehat pada kelompok tertentu sesuai dengan jenis penyakit yang akan dideteksi dini dengan upaya meningkatkan kesadaran pencegahan dan diagnosis dini bagi kelompok yang termasuk resiko tinggi. Skrining/penapisan tidak dilakukan untuk mendiagnosa kehadiran suatu penyakit, tetapi untuk memisahkan populasi subjek skrining/penapisan menjadi dua kelompok yaitu orang-orang yang lebih beresiko menderita penyakit tersebut dan orangorang yang cenderung kurang beresiko terhadap penyakit tertentu. Mereka yang mungkin memiliki penyakit (yaitu, mereka yang hasilnya positif) dapat menjalani pemeriksaan diagnostik lebih lanjut dan melakukan pengobatan jika diperlukan.

\section{Promosi Kesehatan}

Promosi Kesehatan adalah upaya untuk meningkatkan kemampuan masyarakat melalui pembelajaran dari, oleh, untuk dan bersama masyarakat, agar mereka dapat menolong dirinya sendiri serta mengembangkan kegiatan yang bersumber daya masyarakat, sesuai sosial budaya setempat dan didukung oleh kebijakan publik yang berwawasan Kesehatan [10]

Pada tahun 1986 di Ottawa Kanada, berlangsung Konferensi Internasional Promosi Kesehatan yang menghasilkan Piagam Ottawa, yang berisi Aktivitas utama Promosi Kesehatan adalah Advokasi atau Advocating, Pemberdayaan atau Enabling dan Mediasi atau Mediating, dan merumuskan 5 komponen utama promosi kesehatan adalah :

1) Membangun kebijakan publik berwawasan kesehatan atau build healthy public policy.

2) Menciptakan lingkungan yang mendukung atau create supportive environment.

3) Memperkuat gerakan masyarakat atau strengthen community action
4) Mengembangkan keterampilan individu atau develop personal skill

5) Reorientasi pelayanan kesehatan atau reorient helth services.

\section{METODE}

Metode yang digunakan dalam pengabdian masyarakat adalah 1) Pemeriksaan kadar gula sewaktu dengan menggunakan Multi Monitoring System Autocheck, melalui pembuluh darah perifer, yang diambil pada ujung jari tangan, 2) Promosi kesehatan tentang penyakit Diabetes Melitus pada kelompok Karang Werda dengan menggunakan metode ceramah, materi melalui sosial media dan tanya jawab. Kegiatan Promosi Kesehatan dengan memperhatikan strategi dasar utama promosi kesehatan yang meliputi : gerakan pemberdayaan (G), bina suasana (B), advokasi (A) dan Kemitraan (K).

\section{Kerangka Pemecahan Masalah}

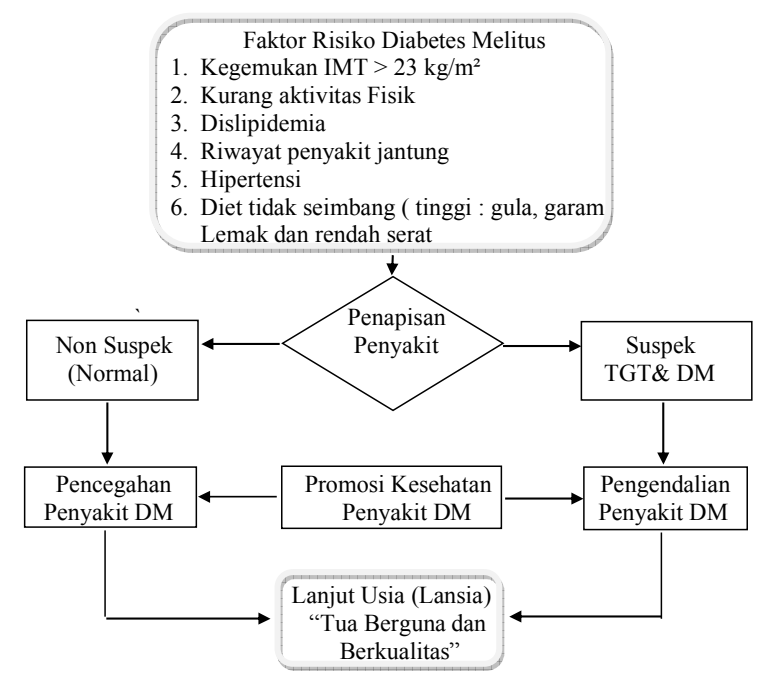

Gambar 1. Kerangka Pemecahan Masalah

Berdasarkan gambar $2.1 \mathrm{di}$ atas, beberapa faktor risiko diabetes melitus antara lain : kememukan, kurangnya aktivitas fisik, dislipidemia, riwayat penyakit jantung, hipertensi, diet yang tidak seimbang. Penapisan bertujuan untuk membedakan antara yang kemungkinan atau suspek diabetes melitus dengan yang yang kemungkinan sehat, kedua kelompok ini perlu upaya pencegahan dan pengendalian penyakit diabetes melitus antara lain melalui promosi kiesehatan dalam upaya tercapainya 
tujuan pembinaan lanjut usia yaitu lanjut usia "Tua

Berguna dan Berkualitas".

Realisasi Pemecahan Masalah

Berdasarkan kerangka pemecahan masalah penyakit Diabetes Diatas, maka dilakukan kegiatan pengabdian kepada masyarakat di Kelompok Karang Werda Sejahtera Kelurahan Bendul Merisi Kecamatan Wonocolo Kota Surabaya.

Kegiatan pengabdian masyarakat meliputi :

1. Penapisan Penyakit Diabetes Melitus.

2. Promosi Kesehatan tentang Penyakit Diabetes Melitus.

3. Pemberdayaan anggota Karang Werda Sejahtera dalam pencegahan dan pengendalian penyakit Diabetes Melitus.

Khalayak Sasaran

Sasaran kegiatan pengabdian kepada masyarakat:

1. Anggota Karang Werda Sejahtera Kelurahan Bendul Merisi Kecamatan Wonocolo Kota Surabaya.

2. Pengurus Karang Werda Sejahtera Kelurahan Bendul Merisi Kecamatan Wonocolo Kota Surabaya.

3. Tokoh masyarakat

\section{HASIL DAN PEMBAHASAN}

\section{Penapisan penyakit DM.}

Hasil kegiatan penapisan terhadap penyakit Diabetes Melitus seperti tersebut pada Tabel 1 sebagai berikut:

Status Kadar Gula Sewaktu (GDS).

Tabel 1. Status Kadar Gula Sewaktu (GDS).

\begin{tabular}{lcc}
\hline \multicolumn{1}{c}{ Status Kadar Gula Sewaktu } & Jumlah & $(\%)$ \\
\hline Normal & 44 & 81,48 \\
Toleransi Glukosa Terganggu & 7 & 12,96 \\
$\begin{array}{l}\text { (TGT) } \\
\text { Diabetes Melitus }\end{array}$ & 3 & 5,56 \\
\hline \multicolumn{1}{c}{ Total } & 54 & 100,00 \\
\hline
\end{tabular}

Dari Tabel 1 di atas ditemukan kasus Diabetes melitus sebesar 3 orang atau 5,56\%, sedangkan status normal merupakan kasus terbanyak yaitu 44 orang atau $81,48 \%$.

Status Kadar GDS berdasarkan jenis kelamin

Tabel 2. Hubungan Diabetes Melitus (GDS) dengan jenis kelamin

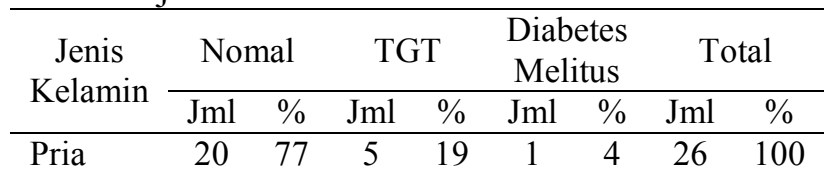

\begin{tabular}{lcccccccc} 
Wanita & 24 & 86 & 2 & 7 & 2 & 7 & 28 & 100 \\
\hline Total & 44 & 81 & 7 & 13 & 3 & 6 & 54 & 100 \\
\hline
\end{tabular}

Dari Tabel 2. di atas di dapatkan dari 26 yang berjenis kelamin pria, sebagian $(77 \%)$ kadar gula darah sewaktu normal. Dari 28 yang berjenis kelamin perempuan, sebagian besar (86) normal.

Status Kadar Gula Darah Sewaktu dengan IMT

Tabel 3. Hubungan Diabetes Melitus (GDS) dengan Indek Masa Tubuh (IMT)

\begin{tabular}{ccccccccc}
\hline $\begin{array}{c}\text { Indek Masa } \\
\text { Tubuh }\end{array}$ & \multicolumn{2}{c}{ Nomal } & \multicolumn{2}{c}{ TGT } & \multicolumn{2}{c}{$\begin{array}{c}\text { Diabetes } \\
\text { Melitus }\end{array}$} & \multicolumn{2}{c}{ Total } \\
\cline { 2 - 9 }$(\mathrm{IMT})$ & $\mathrm{Jml}$ & $\%$ & $\mathrm{Jml}$ & $\%$ & $\mathrm{Jml}$ & $\%$ & $\mathrm{Jml}$ & $\%$ \\
\hline Kurus & 0 & 0 & 0 & 0 & 0 & 0 & 0 & 100 \\
Normal & 14 & 93 & 1 & 7 & 0 & 0 & 15 & 100 \\
Kegemukan & 19 & 68 & 6 & 21 & 3 & 11 & 28 & 100 \\
Obesitas & 11 & 100 & 0 & 0 & 0 & 0 & 11 & 100 \\
\hline Total & 44 & 81 & 7 & 13 & 3 & 6 & 54 & 100 \\
\hline
\end{tabular}

Dari Tabel 3. di atas di dapatkan dari 15 orang yang status gizi normal. sebagian besar (93\%) kadar GDS normal, dari 28 orang yang status gizi kegemukan, sebagian besar (68\%) kadar GDS normal, dari 11 orang yang status gizi obesitas, seluruhnya (100\%) kadar GDS normal.

\section{Hasil Kegiatan Promosi Kesehatan}

1. Topik : Penyakit Diabetes Melitus

2. Materi : Pengertian DM, Epidemiologi DM, Klasifikasi DM, Faktor Risoko DM, Tanda dan Gejala DM, Komplikasi DM, Pencegahan DM, Pengobatan DM.

3. Strategi : Kemitraan, Bina suasana (B), Advokasi (A) dan Gerakan

4. Sasaran : Kelompok pemberdayaan $(\mathrm{G})$.

5. Metode : Ceramah dan tanya jawab

6. Peralatan: Lattop, layar, software (PPT), pengeras suara, Hand Phone atau HP untuk penyampaian materi melalui Whatsapp.

7. Peserta : 54 orang

\section{Pembahasan}

Penapisan Penyakit Diabetes Melitus.

Dari tabel 1. di atas ditemukan kasus Diabeter melitus sebesar 3 orang atau 5,56\%, sedangkan status normal merupakan kasus terbanyak yaitu 44 orang atau $81,48 \%$. Angka diabetes melitus di Kota Surabaya sebesar 4,6\% [11]. Berdasarkan Riskesdas Tahun 2013-2018, prevalensi diabetes melitus berdasarkan diagnosis dokter pada penduduk umur 15 tahun ke atas provinsi jawa timur 2,1\% pada tahun 2013 naik menjadi 2,6\% pada tahun 2018 . 
Prevalensi kasus diabetes melitus pada Lansia di Panti Sosial Tresna Werdha Sabai Nan Aluih Sicincin, sebesar. 14.91\% [11]. Dibandingkan dengan angka diabetes melitus di Kota Surabaya dan di Jawa Timur, Angka diabetes melitus di Karang Werda Sejahtera relatif lebih tinggi oleh karena populasinya adalah lanjut usia, sedangkan dibandingkan dengan prevalensi Panti Sosial Tresna Werdha Sabai Nan Aluih Sicincin angkanya jauh lebih kecil, hal ini kemungkinan upaya melakukan perilaku hidup sehat terutama asupan makanan dan minuman lebih baik, hal ini ditunjang pada umumnya adalah anggota karangwerda yang aktif adalah pesiunan PNS, BUMN dan TNI-Polri.

Berdasarkan Tabel 2. pada wanita ditemukan $86 \%$ adalah normal sedangkan pada pria adalah $77 \%$ Normal. Berdasarkan Riskesdas Tahun 2018, prevalensi diabetes melitus pada wanita lebih tinggi dari pada pria, yaitu prevalensi pada wanita sebesar $1,8 \%$ sedangkan prevalensi pada pria sebesar $1,2 \%$. Di Panti Sosial Tresna Werdha Sabai Nan Aluih Sicincin didapatkan lansia pria yang memiliki kadar glukosa darah normal sekitar $84,21 \%$ dan lansia wanita yang memiliki kadar glukosa darah normal sekitar 87,50\% [12]. Berdasarkan data tersebur di atas persentase yang berjenis kelamin wanita dengan kadar gula darah normal sesuai dengan penelitian Hayyumahdania, wanita dengan kadar gula darah normal lebih tinggi dibandingkan pria, hal ini dikemungkinan disebabkan oleh karena wanita lebih baik menerapkan pola hidup sehat, wanita lebih aktif mengikuti kegiatan karang werda sehingga lebih banyak mendapatkan informasi perilkaku hidup sehat.

Berdasarkan Tabel 3. di atas di dapatkan bahwa dari yang status gizi normal. sebagian besar atau 93\% kadar gula darah sewaktu normal, dari yang status gizi kegemukan, sebagian besar atau $68 \%$ kadar gula darah sewaktu normal dan dari yang status gizi obesitas, seluruhnya atau $100 \%$ kadar gula darah sewaktu normal. Penderita yang obesitas didapatkan $33,8 \%$ dengan kadar gula buruk yaitu diatas 180 $\mathrm{mg} \%$, dan terdapat hubungan antara obesitas dengan kadar gula darah [13]. Berdasarkan data di atas pada obesitas yang menderita diabetes melitus lebih rendah dari pada dengan status kegemukan, hal ini kemungkinan adanya kesadaran pada lansia bahwa obesitas merupakan faktor resiko terjadinya diabetes melitus, sehingga menimbulkan kewaspadaan yang tinggi dengan mererapkan perilaku hidup sehat guna mencegah meningkatkan kadar gula darah.

\section{Promosi Kesehatan tentang Penyakit Diabetes Melitus.}

Pemilihan topik Diabetes Melitus adalah atas permintaan anggota Karang Werda, sehingga topik ini sudah sesuai dengan kebutuhan dari anggota Karang Werda Sejahtera. Seluruih materi sudah disampaikan semua yang meliputi Pengertian DM, Epidemiologi DM, Klasifikasi DM, Faktor Risoko DM, Tanda dan Gejala DM, Komplikasi DM, Pencegahan DM, Pengobatan DM, dan mendapatkan perhatihan dari 54 peserta yang hadir, dengan bukti terdapat peserta yang mengajukan pertanyaan. Semua pertanyaan sudah dijawab dan cukup memuaskan bagi peserta. Penyuluhan dilaksanakan dengan metode kelompok oleh karena hanya diberi waktu 1 (satu) jam untuk kegiatan penyuluhan. Waktu satu jam dirasa cukup untuk pemberian penyuluhan secara kelompok. Penyuluhan lebih menarik dengan menggunakan teknologi mempergunakan software Powerpoint selain ditampilkan di layar juga ditampilkan di Whats App Group.

\section{Upaya Tindak Lanjut}

Diharapkan dengan kegiatan ini terdapat upaya bagi anggota Karang Werda Sejahtera Bendul Merisi untuk melaksanakan upaya pencegahan dan pengendalikan penyakit diabetes melitus.

Upaya pencegahan dan pengendalian penyakit Diabetes Melitus seperti tersebut pada Gambar 2. sebagai berikut:

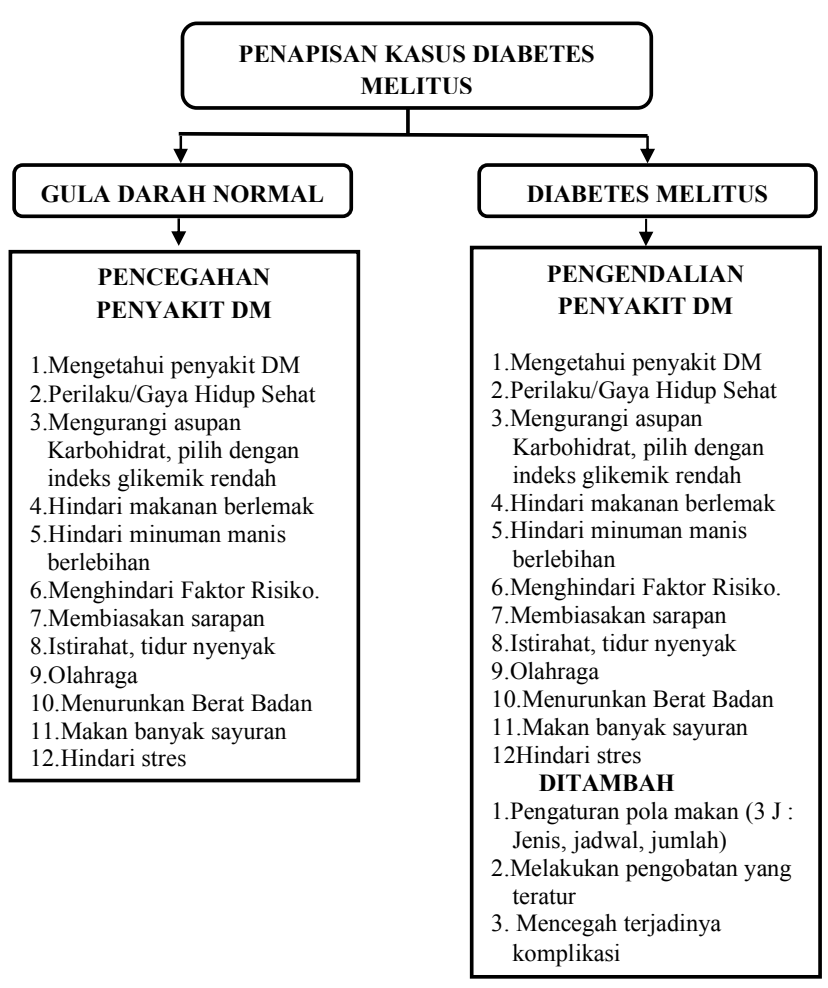

Gambar 2. Upaya pencegahan dan pengendalian penyakit Diabetes

Berdasarkan hasil penapisan kasus diabetes melitus dapat diketahui lanjut usia yang mempunyai 
gula darah normal dan lanjut usia yang kemungkinan diabetes melitus. Yang kemungkinan diabetes melitus perlu dilaksanakan diagnosis yang pengukuran gula darah puasa dan gula darah 2 jam setelah makan serta pengukuran seta pengukuran HbA1c. Sedangkan materi penyuluhan ditujukan kepada upaya pencegahan dan upaya pengendalian penyakit diabetes melitus.

\section{KESIMPULAN}

1. Ditemukan suspek Diabetes Melitus sebesar $5,56 \%$, dan kenbanyakan dengan status normal yaitu sebesar $81,48 \%$.

2. Di dapatkan dari $4 \%$ yang berjenis kelamin lakilaki suspek Diabetes Melitus, dan 7\% dari yang berjenis kelamin perempuan suspek diabetes melitus.

3. Didapatkan $11 \%$ dari yang status gizi kegemukan suspek Diabetes Melitus.

4. Promosi kesehatan tentang upaya pencegahan penyakit diabetes melitus telah dilaksanakan, diikuti oleh 54 orang dan mendapatkan perhatian dengan antusias.

\section{SARAN}

1. Upaya promosi kesehatan dan penapisan tentang penyakit diabetes melitus perlu dilaksanakan secara kesinambungan guna upaya pencegahan dan pengendalian penyakit diabetes melitus pada anggota Karang Werda Sejahtera Bendul Merisi.

2. Perlu adanya promosi dan penapisan untuk penyakit yang lain dalam upaya pencegahan dan pengendalian penyakit pada anggota Karang Werda Sejahtera Bendul Merisi, guna mewujudkan Lanjut usia Tua, berguna dan berkwalitas.

3. Kerjasama antara Universitas Muhammadiyah dan Karang Werda Sejahtera Bendul Merisi perlu dilanjutkan kegiatan-kegiatan selanjutnya yang saling menguntungkan.

\section{DAFTAR PUSTAKA}

[1] Gubernus Jatim, (2017). 'Peraturan Gubernur Provinsi Jawa Timur Nomor 31 Tahun 2017 tentang Karang Werda', Surabaya [0n line], Available: www.peraturan.bpk.go.id.
[2] Lurah Bendul Merisi, Laporan Demografi Kelurahan Bendul Merisi, Surabaya, Indonesia, 2019.

[3] Karang Werda Sejahtera, Laporan Tahun Karang Werda Sejahtera, Bendul Merisi, Wonocolo, Surabaya, Indonesia, 2019.

[4] Kemenkes RI, (2018). Riset Kesehatan Dasar 2018, [0n line], Available: www.depkes.go.id.

[5] Presiden RI, (1998). Undang-undang RI Nomor 13 Tahun 1998 tentang Kesejahteraan Lanjut Usia atau Lansia, [0n line], Available: http://www.bphn.go.id/data/documents/98uu0 13.pdf.

[6] Presiden RI. (2009). Undang-Undang RI Nomor 36 Tahun 2009 tentang Kesehatan, [0n line], Available: www.depkes.go.id.

[7] Sylvia \& Lorraine, Pankreas: Metabolisme Glukose dan Diabetes Melitus. Patofisiologi Konsep Klinik Proses Proses Penyakit, Edisi 6. Jakarta: EFC. 2005. Bab 10, Sub Bab 63, pp 1259-1273.

[8] Depkes RI, Pendahuluan, Pedoman Pengendalian Diabetes Melitus dan Penyakit Metabolik. Jakarta: Depkes RI, 2008. Bab 1, Sub Bab A, pp 1-4.

[9] Perkeni, Definisi, Patogenesis, Klasifikasi, Konsensus Pengelolaan dan Pencegahan Diabetes Melitus Tipe 2 Di Indonesia 2015. Jakarta : Penerbit PB. Perkeni, 2015. Bab III, Sub Bab 3, pp 10.

[10] Depkes RI, (2017). Peraturan Menteri Kesehatan Nomor 585/Menkes/SK/V/2007 tentang Pedoman Pelaksanaan Promosi Kesehatan. Di Puskesmas. Jakarta. [On Line\} Available : https://prokes.kemkes.go.id.

[11] Sofia Rachmawati, (2019). Dinkes: Tren Meningkat, Perlu Preventif Prediabetes. [On Line], Available: https://radarsurabaya.jawapos.com/read/2019/07 /17/146694/dinkes-tren-meningkat-perlupreventif-prediabetes.

[12] Hayyumahdania Reswan, Yustini Alioes dan Rauza Sukma Rita (2017). Gambaran Glukosa Darah pada Lansia di Panti Sosial Tresna Werdha Sabai Nan Aluih Sicincin. Jurnal Kesehatan Andalas. 2017; 6(3). Hal 673-678.

[13] Muladi (2017). Hubungan Status Gizi dengan Kadar Gula Darah Pada Penderita Diabetes Melitus Tipe II di Desa Morodemak. Skripsi. Fakultas Keperawatan dan Kesehata, Universitas Muhammadiyah Semarang. Indonesia, [On Line], Avaiable: http://repository.unimus.ac.id/566/1/ABSTRAK. 
